\title{
ESTRATIGRAFIA DE SEQÜÊNCIAS DA PLATAFORMA MISTA NEOGÊNICA NA BACIA POTIGUAR, MARGEM EQUATORIAL BRASILEIRA
}

\author{
OTAVIANO DA CRUZ PESSOA NETO
}

\begin{abstract}
SEQUENCE STRATIGRAPHY OF THE NEOGENIC MIXED PLATFORM OF POTIGUAR BASIN The aim of this paper is the tertiary mixed siliciclastic-carbonate platform in the Potiguar Basin. The main goal is to address answers to some questions about mixed siliciclastic-carbonate settings, such as depositional shelf dynamics, lateral and vertical facies and their response to sea level variations, questions that have seldom been dealt with or published. The study area covers over $2500 \mathrm{~km}^{2}$, it is located in the basin's submersed portion, it has as its offshore limit the $200 \mathrm{~m}$ bathymetry and it concentrates only on the coastal, shelf and upper slope facies. The section of this study comprises part of the Neogenic sedimentary rocks, which is composed of three lithostratigraphic units known as the Tibau Formation (sandstones and conglomerates), the Guamaré Formation (limestones), and the Ubarana Formation (marine shales). These units make up a large regressive cycle, starting at the Late Campanian through to Holocene. They form a seaward thickening coastal-shelf-slope-basin system. The present paper focuses on a section deposited on the shelf after an Early Miocene erosional unconformity whose angular feature is easily recognized in the submersed portion of the Potiguar Basin, as well as in other basins on the Brazilian coast. The method used in the present study was the integrated stratigraphic analysis, based on sequence stratigraphy concepts through seismic stratigraphy, well logs and biostratigraphy. The integrated approach of the data allowed a subdivision of the section under study in $3^{\text {rd }}$ order depositional sequences, which were detailed in system tracts and higher frequency sequences. The stratigraphic framework obtained allowed for the proposal of a more refined depositional model for the Neogenic mixed platforms in the area under this study.
\end{abstract}

Keywords: Sequence Stratigraphy, Neogene, Seismic Stratigraphy., Stable Isotopes, Carbonate

\begin{abstract}
Resumo O tema do trabalho é a plataforma mista (siliciclástica-carbonática) terciária da Bacia Potiguar. O objetivo principal do mesmo foi tentar responder a algumas questões pouco abordadas ou publicadas sobre os ambientes mistos, tais como a dinâmica da sedimentação na plataforma, a distribuição lateral e vertical de fácies e sua resposta às variações relativas do nível do mar. A área escolhida tem cerca de $2500 \mathrm{~km}^{2}$, localizada na porção submersa da bacia, com limite offshore na cota batimétrica de $200 \mathrm{~m}$, focalizando apenas as fácies litorâneas, de plataforma e talude superior. A seção estudada compreende parte das rochas sedimentares do Neogeno, composta por três unidades litoestratigráficas denominadas Formação Tibau (arenitos e conglomerados), Formação Guamaré (calcários) e Formação Ubarana (folhelhos marinhos). Estas unidades compõem um grande ciclo regressivo iniciado no Neocampaniano, estendendo-se até o Holoceno, formando um sistema costeiro-plataforma-talude-bacia. O trabalho enfoca a seção depositada na plataforma a partir de um evento erosivo de idade comiocênica, cuja discordância angular é facilmente reconhecida na porção submersa da Bacia Potiguar, bem como em várias outras bacias da margem brasileira. A metodologia utilizada consistiu da análise estratigráfica integrada da seção escolhida, utilizando como pressupostos os conceitos da estratigrafia de seqüências, através da sismoestratigrafia, do estudo de perfis de poços e bioestratigrafia. A partir da abordagem integrada destes dados foi possível a subdivisão da seção estudada em seqüências deposicionais de $3^{\text {n }}$ ordem, detalhadas em tratos de sistemas e sequiências de mais alta frequiência. $\mathrm{O}$ arcabouço estratigráfico obtido permitiu a proposição de um modelo deposicional mais refinado para as plataformas mistas do Neogeno na área estudada.
\end{abstract}

Palavras-chave: Estratigrafia de sequiências, Neogeno, Estratigrafia Sísmica, Isótopos estáveis, Carbonatos

INTRODUÇÃO A sedimentação mista na plataforma da Bacia Potiguar foi implantada a partir do Neocampaniano e assim permanece até os dias atuais, com a coexistência de sistemas deposicionais siliciclásticos e carbonáticos, sendo os primeiros dominantes na porção proximal da bacia e os últimos na porção distal ou borda da plataforma. Das relações verticais e laterais das fácies, dadas pela alternância destes sistemas ao longo do tempo, resultou um registro litológico complexo, compreendido em três unidades litoestratigráficas: a Formação Tibau, composta de arenitos e conglomerados, derivados dos sistemas de leques costeiros e do preenchimento de vales incisos; a Formação Guamaré, composta de calcarenitos e calcilutitos, originados de bioconstruções e bancos algálicos na borda da plataforma; e a Formação Ubarana, composta de folhelhos, calcilutitos e arenitos subordinados, representando a sedimentação recíproca oriunda da plataforma e depositada em ambiente de talude.

O uso puro e simples da litoestratigrafia, pelas limitações que lhe são inerentes, não tem sido suficiente para descrever a distribui- 
ção temporal e espacial do registro sedimentar da bacia: "As relações verticais e laterais dos sistemas deposicionais são melhor compreendidas quando analisadas em um contexto cronoestratigráfico, estabelecido pela abordagem da estratigrafia de sequiências. Este trabalho propõe um arcabouço cronoestratigráfico de parte do registro da plataforma mista na Bacia Potiguar, preenchido por sequiências deposicionais formadas durante o Neogeno. Para a proposição desse arcabouço foram utilizados dados sísmicos e de poços da seção neogênica, visando três objetivos principais: (i) determinação dos principais eventos geológicos que moldaram o registro estratigráfico da bacia nesse período; (ii) a proposição de um modelo deposicional consistente, que explique as relações vertical e lateral de fácies; (iii) e a correlação de eventos locais com aqueles de amplitude regional e/ou global.

Foram utilizadas três ferramentas de análise estratigráfica: a sismoestratigrafia, a bioestratigrafia e a correlação de perfis elétricos, aplicadas aos dados sísmicos e de poços da seção neogênica da Bacia Potiguar. A integração dessas ferramentas permitiu o desenvolvimento de um arcabouço tectono-estratigráfico que explora as variações laterais e verticais das fácies siliciclásticas e carbonáticas.

\section{ARCABOUÇO TECTONO-ESTRATIGRÁFICO DA BACIA} POTIGUAR Evolução tectônica A Bacia Potiguar está situada no limite entre as margens leste e equatorial brasileiras, estando a sua origem diretamente ligada à evolução destes dois segmentos da Placa sul-americana (Fig.1).

A história tectônica da Bacia teve início no Neocomiano e pode ser dividida em três fase distintas, identificadas por Bertani et al (1990), quais sejam, rifte, transicional e deriva continental. O preenchimento sedimentar da bacia durante cada uma destas fases tectônicas foi caracterizado, respectivamente, pela deposição das megasseqüências continental, transicional e marinha (Chang \& Kowsmann,1987, Chang et al 1992)

FASE RIFTE (NEOCOMIANO-EOAPTIANO) Caracteriza-se por um regime tectônico rúptil distensivo, com afinamento crustal e formação de grabens assimétricos controlados por grandes falhas normais e de transferência (Matos 1987, 1992). Ao longo destes grabens implantou-se uma sedimentação continental constituída de folhelhos lacustres, arenitos flúvio-deltaicos e depósitos de planície aluvial/planície de inundação. O preenchimento da bacia durante esta fase é representado pela megasseqüência continental, constituída pelos depósitos das formações Pendência e Pescada. Essa fase é síncrona em várias bacias do nordeste brasileiro, como demonstrado por Matos (1987, 1992), sendo caracterizada por um regime tectônico com altas taxas de subsidência e extensão litosférica (Chang \& Kowsmann 1987, Chang et al 1992). Na porção emersa da bacia, esta megasseqüência divide-se em quatro sequiências deposicionais de $3^{\mathrm{a}}$ ordem (Della Fávera et al. 1994).

FASE TRANSICIONAL (NEOAPTIANO - EOALBIANO) Este

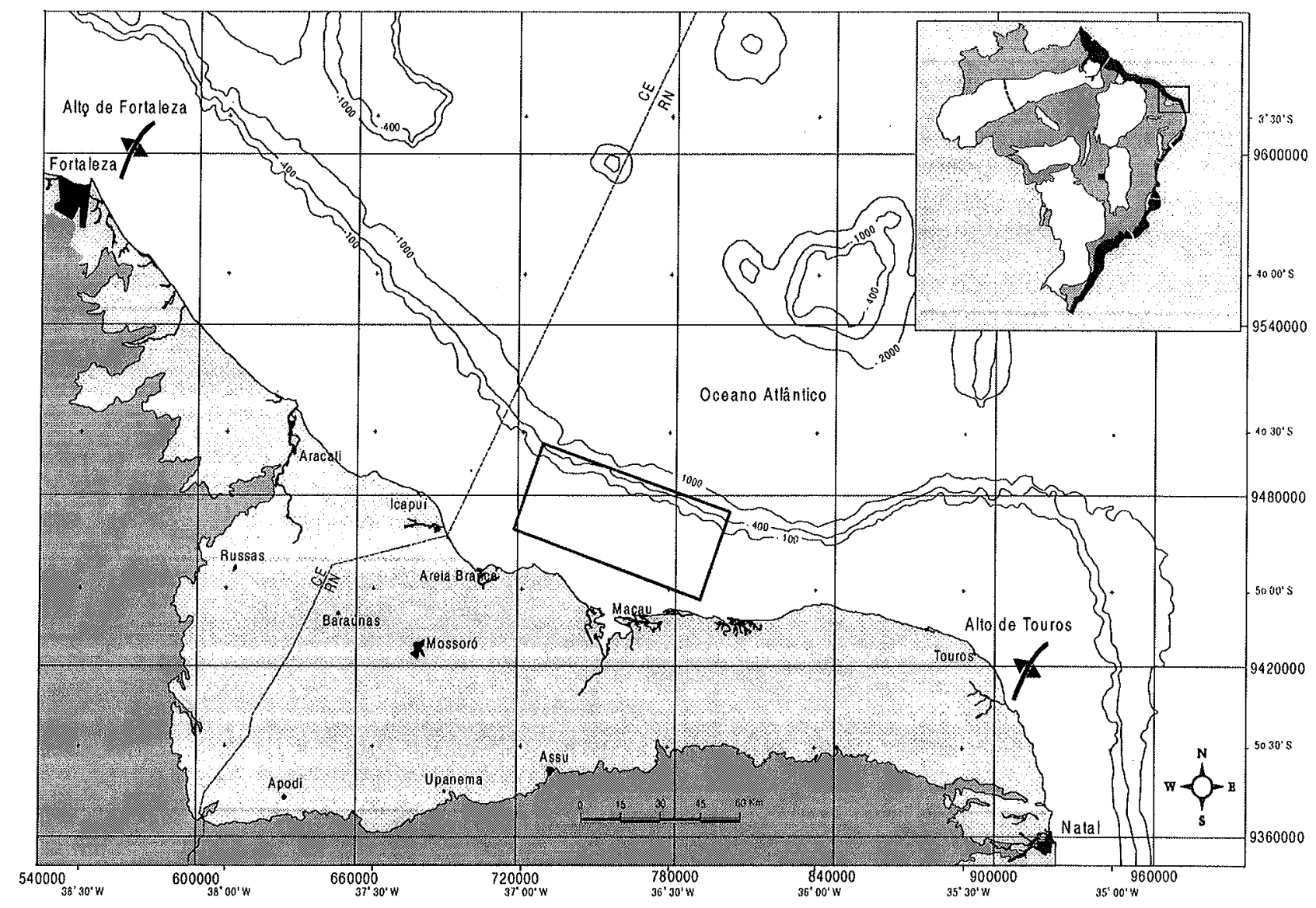

Figura 1 - Mapa de localização da Bacia Potiguar com representação da área de estudo. 
estágio foi marcado por um regime tectônico de relativa quietude, caracterizado por subsidência termal devida ao início do processo de resfriamento da litosfera previamente distendida e aquecida na fase rifte. Depositaram-se nesta fase os folhelhos e calcários lagunares, com influência marinha, intercalados por arenitos deltaicos, que caracterizam a megasseqüência transicional representada pelos sedimentos da Formação Alagamar. A seção superior desta unidade representa a primeira entrada marinha na Bacia Potiguar, registrada nos calcilutitos algálicos e ostracoidais das Camadas Ponta do Tubarão (CPT) (Vasconcelos 1995).

FASE DE DERIVA (ALBIANO - HOLOCENO) Corresponde à fase de deriva continental, caracterizada por uma sedimentação marinha franca. O regime tectônico controlador desta fase é o de subsidência termal e compensação isostática (Chang \& Kowsmann 1987, Chang et al. 1992), típico do contexto de margem passiva. O preenchimento sedimentar da bacia durante a deriva pode ser dividido em duas fases: transgressiva e regressiva.

A fase transgressiva, que se estende Albiano ao Eocampaniano, é representada por sistemas fluviais, costeiros, plataformais, até marinho profundo. A fase regressiva é representada por sistemas deposicionais costeiros-plataforma-talude-bacia, instalados a partir do Neocampaniano, estendendo-se até o Holoceno.

A megassequiência marinha que corresponde ao preenchimento sedimentar desta fase compreende a maior parte da sedimentação ocorrida durante a fase de subsidência térmica plena da bacia, podendo ser dividida em dois conjuntos de sequiências de $2^{\mathrm{a}}$ ordem: transgressivas e regressivas.

As sequiências transgressivas são caracterizadas por uma sedimentação de sistemas fluviais a de ambiente marinho profundo, passando por sistemas carbonáticos de plataforma, implantados entre o Albiano e o Eocampaniano. Estas sequiências englobam rochas das formações Açu, Ponta do Mel, Jandaíra e Quebradas cujo máximo transgressivo correspondente aos folhelhos neocenomanianos conhecidos como Membro Porto do Mangue, da Formação Quebradas. As seqüiências regressivas consistem de sistemas de leques costeiros e bancos carbonáticos progradantes atuantes na bacia a partir do Neocampaniano e que se estendem até os dias atuais. Individualizam-se pelo menos três sequiências neste intervalo, limitadas por discordâncias bem marcadas em seções sísmicas, quebras nos perfis elétricos e descontinuidades bioestratigráficas em poços. A sequiência mais antiga, de idade Neocampaniano-Neopaleoceno, preserva ainda delgadas relíquias de uma plataforma carbonática e principalmente fácies de talude e bacia. Uma sequiência intermediária, de idade Neopaleoceno-Eomioceno, está representada em quase toda a bacia por uma cunha sedimentar, também composta de resquícios de plataforma carbonática, fácies de talude e bacia oceânica. Essa sequiência é limitada no topo por outro importante evento erosivo, datado como eomiocênico (DMI, Fig. 3). A partir deste evento (DMI) instala-se a última sequiência regressiva, objeto deste trabalho, que apresenta um grande deslocamento de fácies em direção à bacia oceânica, marcado pela implantação de carbonatos de plataforma rasa discordantemente sobre fácies de talude das seqüências pretéritas. Esta megassequiência é reconhecida em quase todas as bacias da margem continental brasileira, cujos principais eventos erosivos são correlacionáveis em escala regional.

O preenchimento sedimentar da Bacia Potiguar está expresso na coluna estratigráfica adotada neste trabalho, modificada de Araripe \& Feijó (1994) e Soares et al. (1999), a partir das unidades originalmente definidas por Souza (1982). As unidades litoestratigráficas que compreendem o registro da sedimentação mista neogênica enfocadas neste trabalho são as formações Tibau, Guamaré e Ubarana (Fig. 2). As rochas correspondentes a estas unidades litoestratigráficas compõem um trato deposicional costeiro-plataforma-talude.

ESTRATIGRAFIA DE SEQÜÊNCIAS Os conceitos da Estratigrafia de Sequiências foram utilizados como ferramentas de análise da seção estudada, tendo como referências geocronológicas os dados bioestratigráficos, devidamente ajustados à base de dados sísmicos. Tal ajuste permitiu a interpretação sismoestratigráfica com o caráter geocronológico necessário à montagem do arcabouço proposto.

Biocronoestratigrafia As condições de deposição dos carbonatos na porção rasa das plataformas mistas terciárias da margem atlântica brasileira não favoreceram a proliferação e/ou preservação dos palinomorfos, foraminíferos planctônicos e nanofósseis. Contudo, estes ambientes são caracterizados pela presença de foraminíferos bentônicos de grande porte, os macroforaminíferos, que usualmente apresentam ampla distribuição vertical e lateral. Reconhecidos em quase toda a margem continental brasileira (Abreu \& Viviers 1991), os macroforaminíferos constituem o único grupo fóssil disponível para fundamentar zoneamentos bioestratigráficos em rochas carbonáticas terciárias de ambiente marinho raso (Abreu et al. 1993). Estes organismos foram estudados por Abreu et al. (1993) na seção cenozóica das bacias do ParáMaranhão, Ceará e Potiguar. Nos espessos pacotes carbonáticos depositados em plataforma rasa, os autores estabeleceram um zoneamento bioestratigráfico regional, baseado em estudos taxonômicos e na distribuição estratigráfica dos macroforaminíferos a nível específico, até então conhecidos apenas a nível genérico (Abreu et al. 1986). Este detalhamento melhorou substancialmente a resolução bioestrati-gráfica na seção cenozóica das bacias costeiras, especialmente na porção compreendida entre o Oligoceno Superior e o Mioceno Médio.

Para estabelecer um zoneamento bioestratigráfico detalhado da área foram utilizadas as amostras de calha de um poço de referência (P1). A partir das associações fósseis existentes no poço e do zoneamento regional dos macroforaminíferos, foram identificadas 10 biozonas, entre o Oligoceno Superior e o Pleistoceno, com maior detalhamento entre o Oligoceno e o Mioceno Inferior/Médio (Fig. 4).

Interpretação sismoestratigráfica Dois tipos de superfícieschave foram escolhidos para guiar o mapeamento sismoestratigráfico: as discordâncias e as superfícies de inundação.

As discordâncias identificadas e mapeadas se caracterizaram pela geometria irregular nas seções sísmicas, sendo o rastreamento mais difícil nas seções paralelas à direção do mergulho deposicional (strike), onde as relações entre refletores são mais sutis. Nas seções paralelas ao sentido do mergulho deposicional (dip), as discordâncias foram identificadas por três critérios principais: onlap dos estratos sobre superfícies irregulares contínuas; truncamentos dos estratos subjacentes dados por estas mesmas superfícies; e feições de erosão, como canais e vales escavados sobre a plataforma. As superfícies deposicionais, sobretudo as superfícies de inundação, são de mais fácil identificação, caracterizando-se por reflexões com geometria plana, grande extensão lateral e, em geral, baixa amplitude sísmica. Um outro critério para rastreamento destas superfícies foi a identificação das raras terminações em downlap 
sobre reflexões de baixa amplitude. Este tipo de terminação, no entanto, é raro e de difícil visualização em função dos baixos mergulhos dos estratos na plataforma.

Sequiências deposicionais Da interpretação sismoestratigráfica da área resultou a individualização de sete seqüências deposicionais de $3^{\text {a }}$ ordem, aqui agrupadas segundo sua posição cronoestratigráfica dominante, em três conjuntos de seqüências correspondentes aos andares Mioceno Inferior/Médio, Mioceno Médio e Mioceno Superior/Pleistoceno (Fig. 5, Tabela I).

\section{SEQÜENECIAS DO MIOCENO INFERIOR/MÉDIO(SMI-l, SMI-}

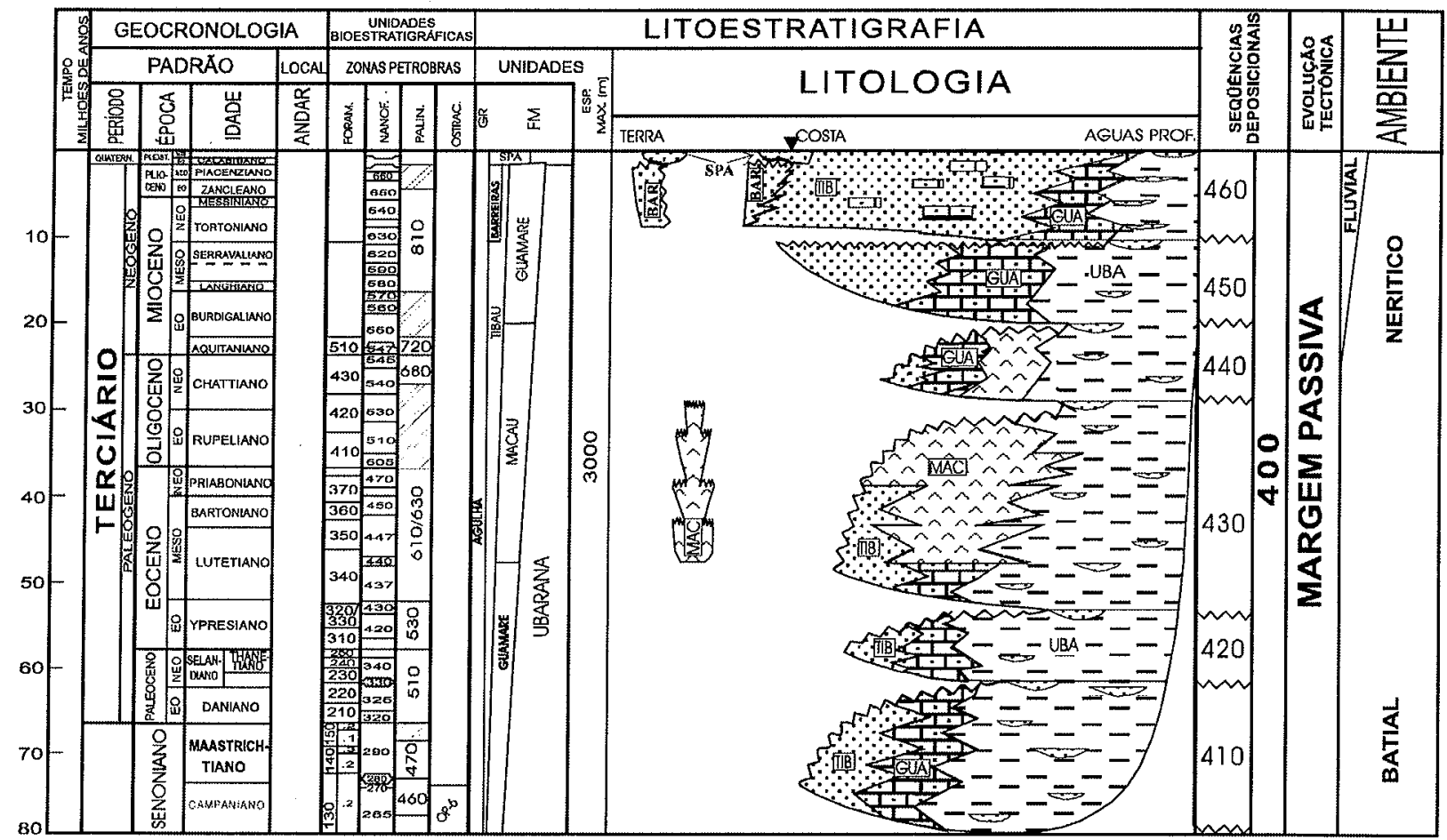

Figura 2 - Carta estratigráfica do Terciário da Bacia Potiguar. Modificada de Araripe \& Feijó (1994) e Soares et al. (1999). A discordância DMI marca o limite inferior da seção estudada.

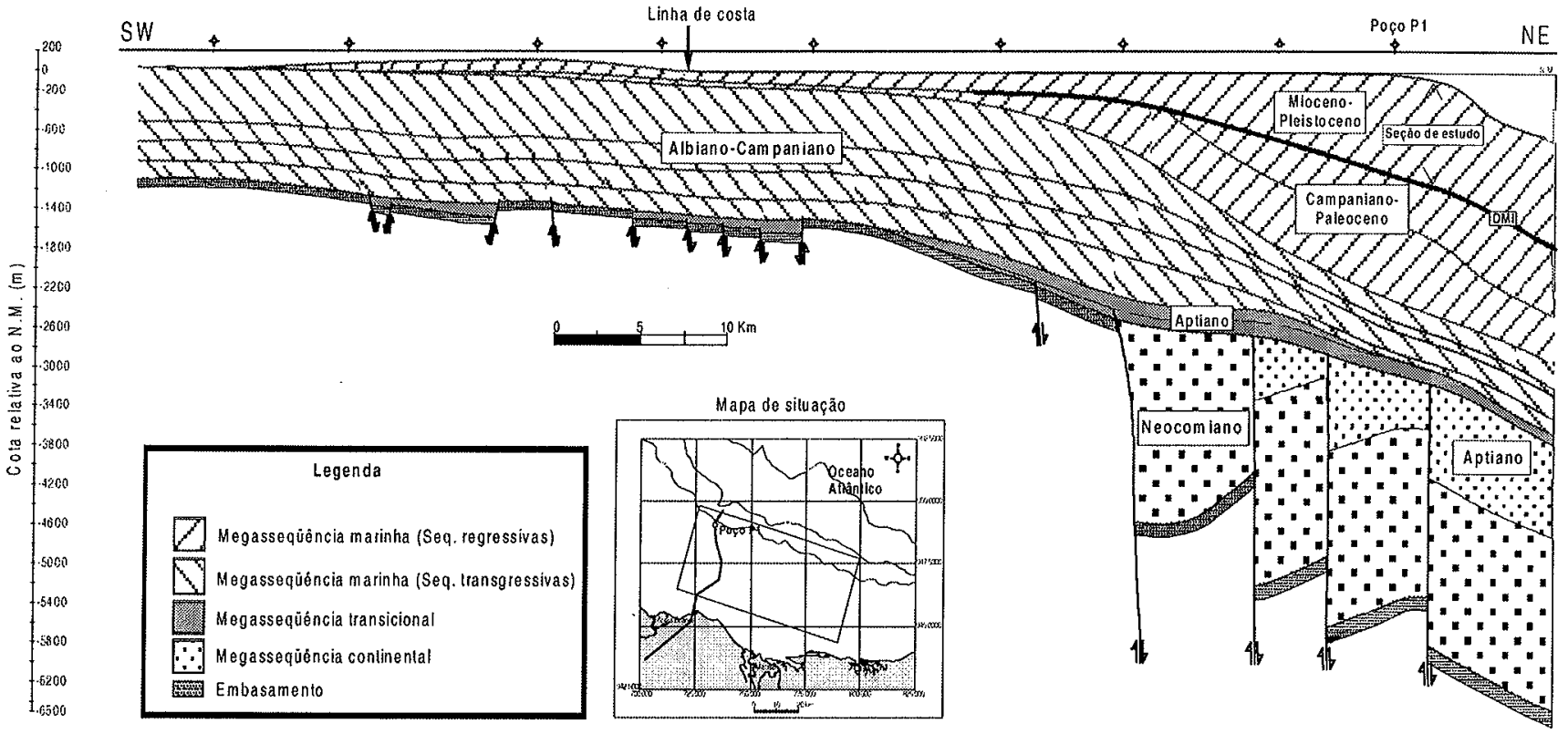

Figura 3 - Seção geológica regional na Bacia Potiguar, passando pelo poço Pl, que serviu de referência para dados litológicos e bioestratigráficos. 


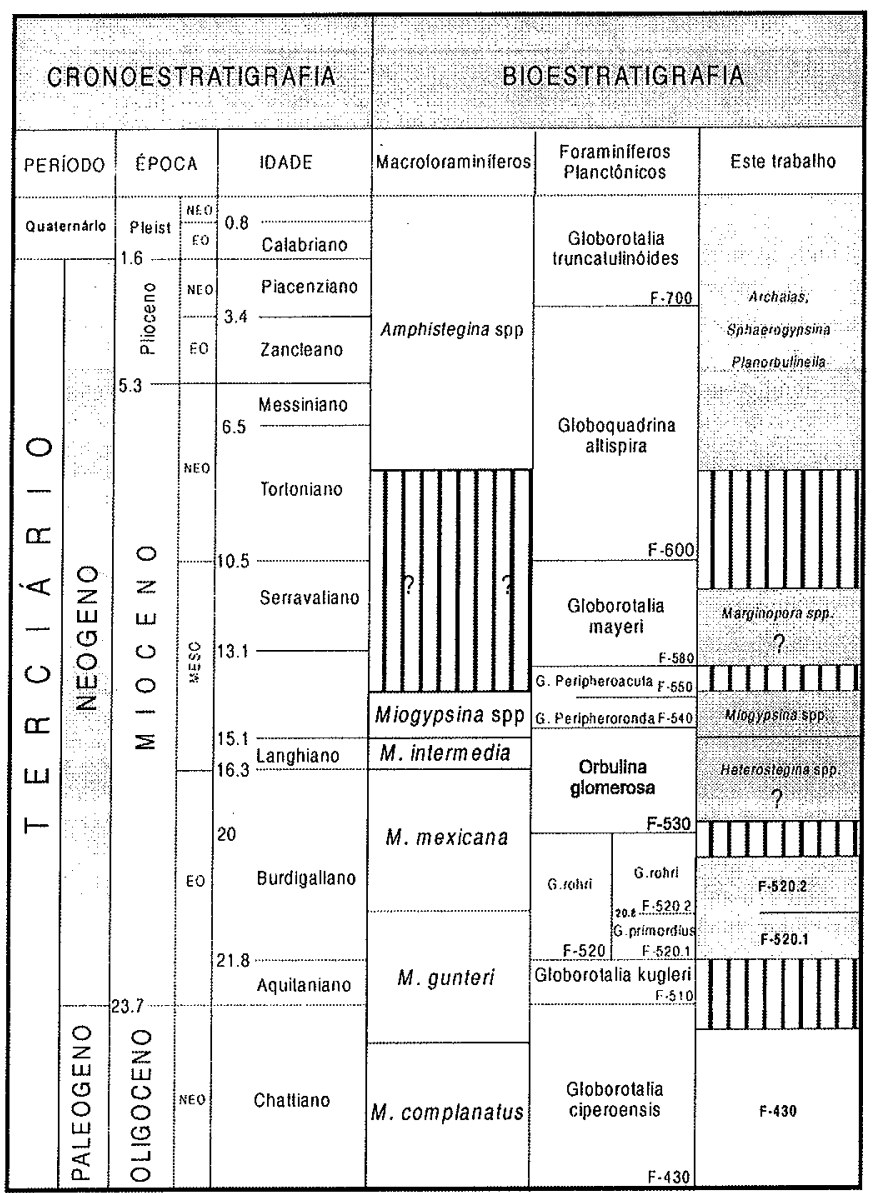

Figura 4 - Arcabouço cronoestratigráfico do Neogeno da Bacia Potiguar. Os dados bioestratigráficos utilizados na montagem deste arcabouço incluem foraminíferos planctônicos $e$ macroforaminiferos bentônicos. Modificado de Abreu et al. (1993).

2) São bastante semelhantes, tanto no que se refere à geometria deposicional, quanto à composição litológica, expressa pela proporção siliciclásticos/carbonatos.

A primeira sequiência sísmica (SMI-1) é limitada na base pela discordância regional DMI e no topo pela discordância DMM-10. Esta última marca a extinção da forma-guia Heterostegina, cujo topo é aqui interpretado como correspondente à base do Mioceno Médio (Langhiano). Esta é uma das mais importantes sequiências mapeadas na seção em virtude da boa definição das biozonas neste intervalo.

As seqüências deste intervalo, entre as discordâncias DMI e DMM-20, são caracterizadas por baixo influxo de sedimentos siliciclásticos, predominando as fácies carbonáticas de plataforma externa. Ao nível da SMI-2, no entanto, o influxo de siliciclásticos é mais expressivo, com a existência de camadas arenosas intercaladas com espessos pacotes de sedimentos carbonáticos. A partir da discordância DMM-20, que limita o topo da sequiência SMI-2, inicia-se uma fase de maior influxo de siliciclásticos na bacia, preferencialmente através de calhas deposicionais implantadas na bacia neste período. Nesta fase ocorre a primeira indicação da associação direta entre as discordâncias mapeadas e o paleovale do Rio Açu (Fig. 6).
SEQÜÊNCIASDO MIOCENOMÉDIO SMM (smm-a, smm-b, smmc) Limitada na base pela discordância DMM-20 e no topo pela discordância DMP-1. Esta seqüência é composta por, pelo menos, três eventos ou sequiências de mais alta frequêencia ( 4 i ordem). A espessura reduzida dos intervalos, abaixo do nível de resolução das seções sísmicas, dificultou o detalhamento sismoestratigráfico das sequiências de alta frequiência. Para contornar esta limitação, recorreu-se à interpretação de perfis de poço, utilizando como critérios básicos os padrões de empilhamento e quebras no registro litológico. Com base nestes critérios, foi possível identificar, no poço $\mathrm{Pl}$, três seqüências deposicionais de $4^{\text {a }}$ ordem contidas na sequiência de $3^{a}$ ordem SMM (smm-a, smm-b, e smm-c).

As discordâncias internas ao intervalo, que limitam as seqüências estão provavelmente associadas a exposições sistemáticas da plataforma. As discordâncias dmm-25 e dmm-30, embora não sendo conspícuas nas seções sísmicas, são visíveis em feições de perfil no poço $\mathrm{P} 1$ e/ou quebras bioestratigráficas. A discordância dmm-25, sismicamente mais evidente, marca a extinção do gênero Miogypsina spp.

\section{SEQÜENCIAS DO MIOCENO SUPERIOR/PLEISTOCENO} (SMP-1, SMP-2 e SMP-3) O intervalo destas sequiências é limitado na base pela discordância DMP-1 e no topo pela discordância DMP-30. A seqüência sísmica SPP, compreendida entre a DMP-30 e o fundo do mar, não foi aqui considerada.

A deposição destas sequiências marca um expressivo aumento de influxo de siliciclásticos na bacia, evidenciado tanto pelas sismofácies dominantes das sequiências, como pelo aumento da razão areia/carbonato nos poços. $\mathrm{O}$ aumento do influxo é observado, sobretudo, nos poços situados próximos às calhas deposicionais da bacia, para onde a drenagem fluvial afluiu a partir do Mioceno Médio. Nestes poços, estas seqüiências se compõem quase exclusivamente de arenitos grossos e delgadas camadas de folhelhos e argilitos.

Sismofácies Além da identificação de superfícies-chave, procurou-se reconhecer as principais sismofácies em algumas seções e interpretar os principais domínios litológicos correspondentes a partir dos poços (Fig. 7). Foram assim identificadas 5 litosismofácies principais:

Sf I- sismofácies caracterizada por reflexões onduladas, subparalelas, descontínuas, litologicamente correspondente a sedimentos siliciclásticos grosseiros de origem flúvio-deltaica;

Sf2- sismofácies caracterizada por reflexões plano-paralelas, contínuas, correspondente às intercalações de carbonatos e siliciclásticos dominantes na plataforma externa;

Sf3- sismofácies com padrão interno de reflexões semelhante à Sf2, mas correspondente a seções de carbonatos puros da porção basal dos poços estudados;

Sf4- sismofácies caracterizada por padrão caótico ou por feições monticulares empilhadas, correspondente ao contexto das bioconstruções e bancos carbonáticos;

Sf5- sismofácies com padrão oblíquo paralelo / subparalelo, correspondente aos pelitos do talude superior e preenchimento dos cânions.

Algumas sismofácies observadas na borda da plataforma foram interpretadas como recifes e bancos algálicos. Estas construções são comumente encontradas próximas aos cânions escavados na borda da plataforma. A ocorrência contígua destas duas feições é aqui interpretada como resultante da captura, pelos cânions, do 


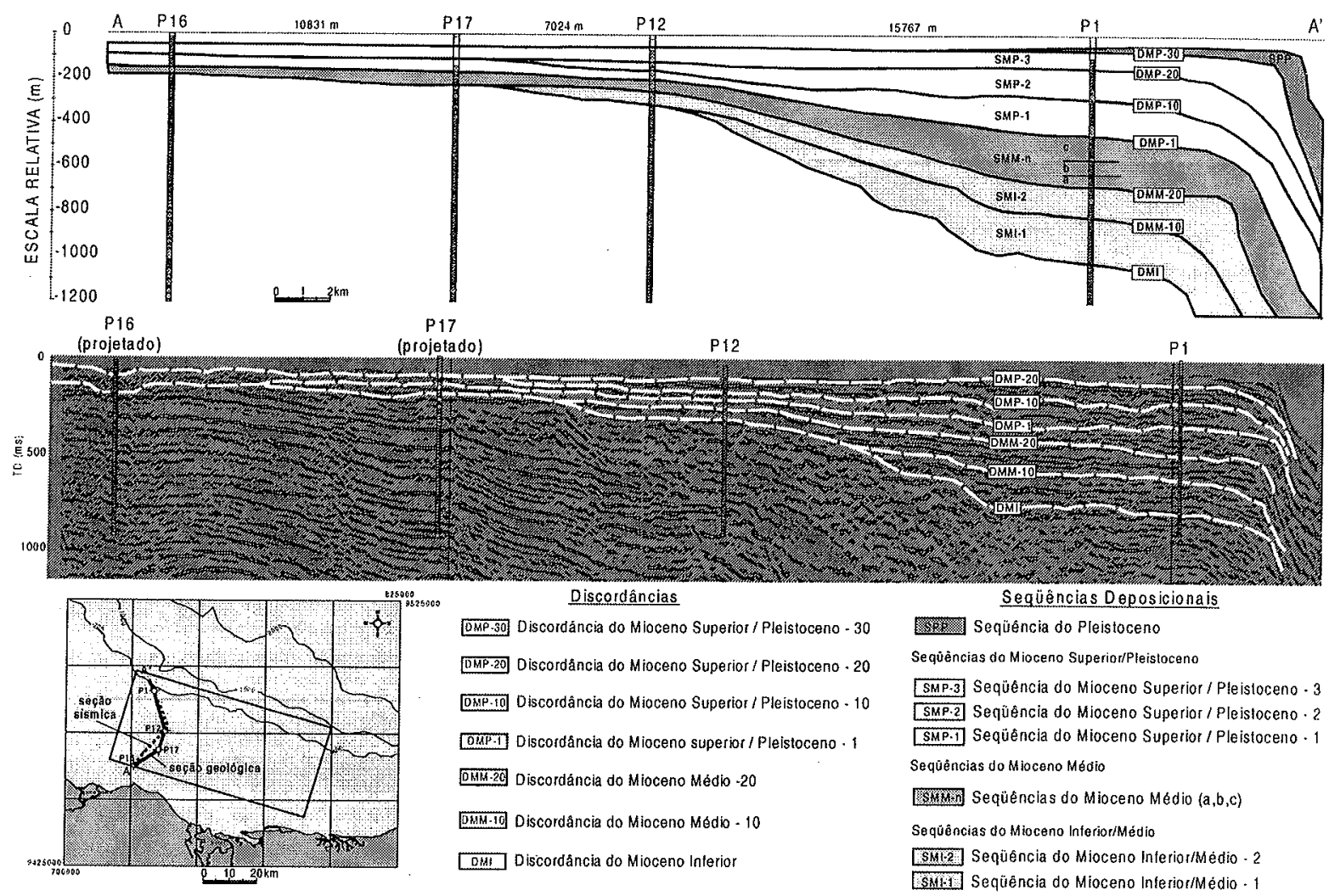

Figura 5 - Sequiências sismoestratigráficas identificadas na área de estudo e seus respectivos limites.

Tabela 1 - Seqüencias estratigráficas identificadas no trabalho com seus respectivos limites e idades.

\begin{tabular}{|c|c|c|c|c|}
\hline \multirow{2}{*}{\multicolumn{2}{|c|}{ Sequiiência }} & \multicolumn{2}{|c|}{ Limites } & \multirow[b]{2}{*}{ Série (Andar) } \\
\hline & & Inferior & Superior & \\
\hline & & DMP-20 & DMP-30 & \multirow{3}{*}{ Mioceno Superior/Pleistoceno } \\
\hline & $\mathrm{P}-2$ & DMP-10 & DMP-20 & \\
\hline & & DMP-1 & DMP-10 & \\
\hline \multirow{3}{*}{ SMM } & smmec & $\mathrm{dmm}-30$ & DMP-1 & \multirow{2}{*}{ Mioceno Médio (Serravaliano) } \\
\hline & smm-b & $\mathrm{dmm}-25$ & $\mathrm{dmm}-30$ & \\
\hline & smmat & DMM-20 & $\mathrm{dmm}-25$ & Mioceno Médio (Langhiano/Serravaliano) \\
\hline \multicolumn{2}{|c|}{ SMI-2 } & DMM-10 & DMM-20 & Mioceno Inferior/Módio (LanghiandSerravaliano) \\
\hline \multicolumn{2}{|c|}{ SMI-1 } & DMI & DMM-10 & Mioceno Inferior/Médio (Burdigaliano/Langhiano) \\
\hline
\end{tabular}

influxo siliciclástico para a bacia marinha, propiciando o desenvolvimento lateral das bioconstruções.

Tratos de sistemas As seqüências identificadas foram tentativamente interpretadas em termos de tratos de sistemas, quais sejam, mar baixo (TSMB), transgressivo (TST) e de mar alto (TSMA), a partir das superfícies-chave, feições sísmicas e seus correspondentes litológicos no poço Pl (Fig. 8).

O trato de sistemas de mar baixo em praticamente todas as sequiências restringe-se, na maior parte da área, aos depósitos de preenchimento de vales incisos na plataforma, pertencentes aos estágios iniciais do período de rebaixamento eustático. O influxo de clásticos foi variável ao longo do período estudado, por vezes insuficiente para o desenvolvimento dos depósitos que caracteri- zam o estágio tardio do trato de mar baixo. Ao nível das sequiências basais (SMI-1 e SMI-2), por exemplo, tais depósitos desenvolvem-se apenas na porção central da área, onde a formação de uma calha mais subsidente propiciou a acomodação dos sedimentos sob a forma de cunhas de mar baixo.

O trato de sistemas transgressivo é reconhecido na sísmica por conjuntos de reflexões em onlap contra as discordâncias, em geral superpostos por uma reflexão de baixa amplitude e grande continuidade. Nos poços, é caracterizado por empilhamento de parasseqüências em granodecrescência ascendente, dadas pela deposição de arenitos e grainstones algálicos coroados por níveis de pack/wackestones, testemunhando o afogamento/ aprofundamento do sistema em cada ciclo (Pessoa Neto 1999). A pequena espessura dos depósitos dificultou a sua identificação nas seções sísmicas em quase toda a área, salvo nas porções mais subsidentes da bacia, onde o potencial de preservação das sequiências é maior, sendo possível visualizar melhor a relação entre os refletores.

O trato de sistemas de mar alto é representado pelos bancos e edifícios carbonáticos na borda da plataforma, visíveis nas seções e imagens sísmicas. Sismicamente se distingue por sutis terminações em downlap sobre as SIM e pelas sismofácies oblíquas. Por efeito de erosão do topo das sequêencias a cada rebaixamento relativo do nível do mar, os depósitos deste trato pouco se preservaram no interior da plataforma. A espessura dos depósitos do TSMA, entretanto, é crescente para o topo, indicando uma melhor preservação da porção superior da sequiência.

\section{INTERPRETAÇÃO DOS RESULTADOS Do campo da}




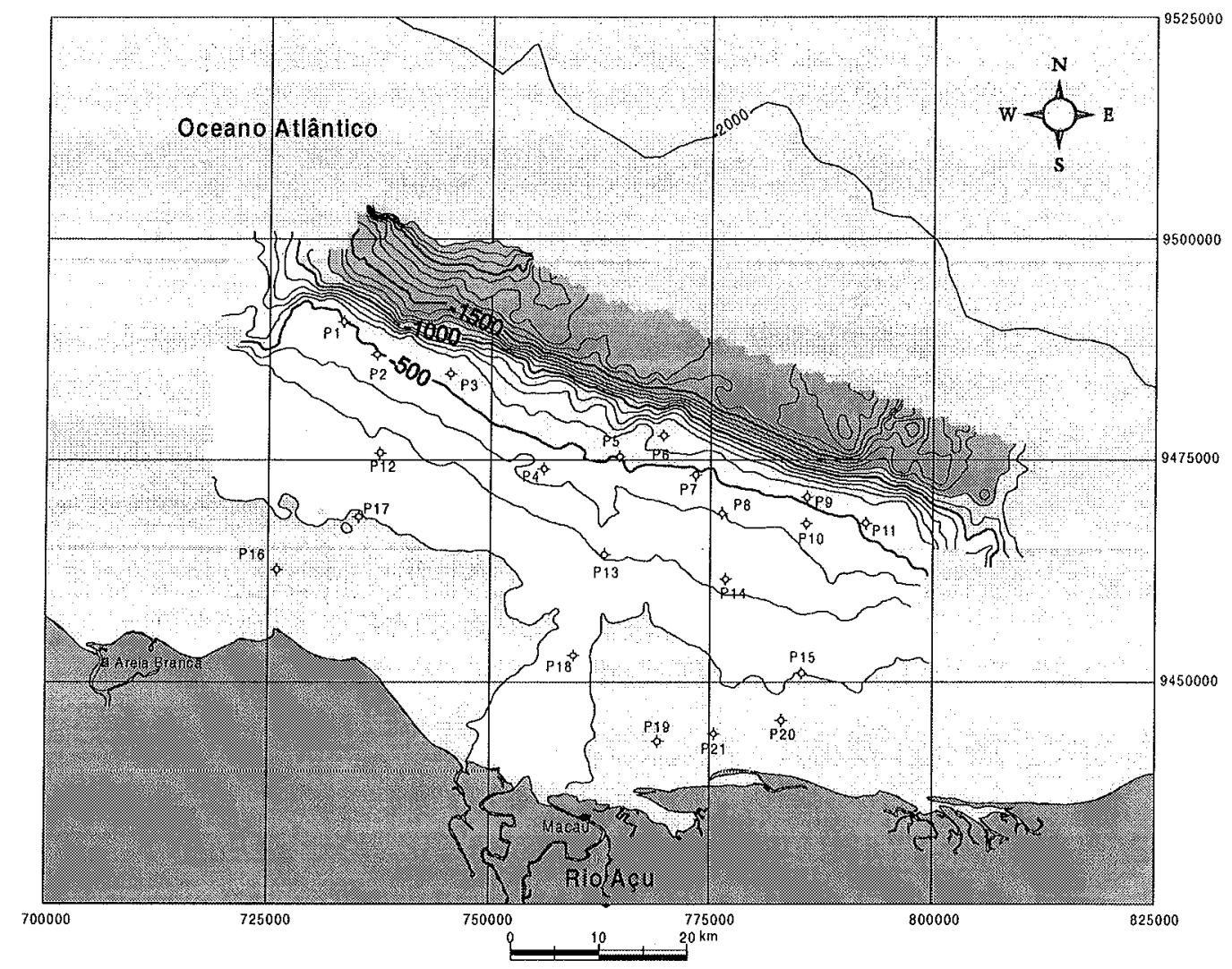

Figura 6-Mapa sísmico em tempo da discordância DMM-10, mostrando a primeira indicação de paleovale do Rio Açu. Tal feição sugere a presença do rio nesta posição desde, pelo menos, o Mioceno Médio. (I.C. $100 \mathrm{~ms}$ ).

sismoestratigrafia, integrada à análise de perfis elétricos de poços, resultaram superfícies e seqüências deposicionais interpretadas indiretamente sobre o registro geológico disponível nas seções sísmicas e perfis elétricos. Do campo da bioestratigrafia, cujos dados são extraídos diretamente do registro geológico de poços, resultaram três grandes domínios cronoestratigráficos: Mioceno Inferior/Médio, Mioceno Médio, Mioceno Superior/Pleistoceno.

As interseções entre as seqüências interpretadas nas seções sísmicas e estes domínios cronoestratigráficos, apresentam coerência quando analisados à luz das variações cíclicas do nível do mar (Fig. 9). A curva de variação do nível do mar apresentada foi interpretada a partir das indicações fornecidas por cada conjunto de dados analisados. Às discordâncias foram associadas quedas relativas do nível do mar, com amplitude inferida a partir da expressão sísmica da superfície erosiva. Os períodos de elevação do nível do mar foram associados às superfícies de inundação identificadas na sísmica e poços, cuja amplitude varia de acordo com a expressão regional destas superfícies.

As variações expressas pela curva são qualitativas no que se refere à amplitude, mas mantêm uma coerência relativa entre os três grandes domínios cronoestratigráficos, refletidos em quase todas as ferramentas. Três ordens ou frequiências de oscilações relativas do nivel do mar estão expressas na curva: (i) uma frequiência mais alta representando ciclos de $4 \mathrm{a}$ ordem superpostos a (ii) uma freqüência intermediária dominante, representando ciclos de $3^{\text {a }}$ ordem e (iii) uma envoltória destes últimos, representando as oscilações de baixa freqüência, possivelmente relacionados aos ciclos de $2^{\text {a }}$ ordem. Esta subdivisão do tempo geológico limita os três grandes períodos da evolução estratigráfica do Neogeno da Bacia Potiguar que representam os três estágios principais detalhados neste trabalho.

Modelo deposicional O modelo proposto para a seção estudada assume as variações relativas do nível do mar, resultantes da interação tectônica-eustasia, como os principais elementos controladores do espaço deposicional disponível para acomodação da sedimentação plataformal mista. Em outras palavras, a base conceitual da estratigrafia de sequiências é aceita como uma ferramenta capaz de explicar satisfatoriamente a evolução deposicional da seção de estudo. A influência do clima, embora não abordada especificamente, vai se traduzir na variável suprimento sedimentar, seja pelo efeito direto sobre a sedimentação carbonática, seja pelo efeito indireto na disponibilidade de siliciclásticos nas áreas fontes. A influência relativa de cada um dos fatores variou ao longo do período considerado no trabalho, embora nem sempre seja possível determinar com segurança o fator preponderante na criação ou redução do espaço deposicional.

Um outro ponto importante a ser considerado é a relação entre a drenagem costeira atual da Bacia Potiguar, composta pelos dois principais rios, Rio Açu e Rio Mossoró, e a sedimentação clástica na plataforma. Os dois rios parecem ter sido ativos nesta área já a partir do Mioceno Médio, atuando como fonte de influxo de siliciclásticos e na sua distribuição na plataforma e talude. A presença da drenagem costeira ativa na plataforma neste período é evidenciada pela ocorrência de cunhas clásticas costeiras, visualizadas nas seções sísmicas e amostradas pelos poços proximais ao longo de toda a área estudada. 

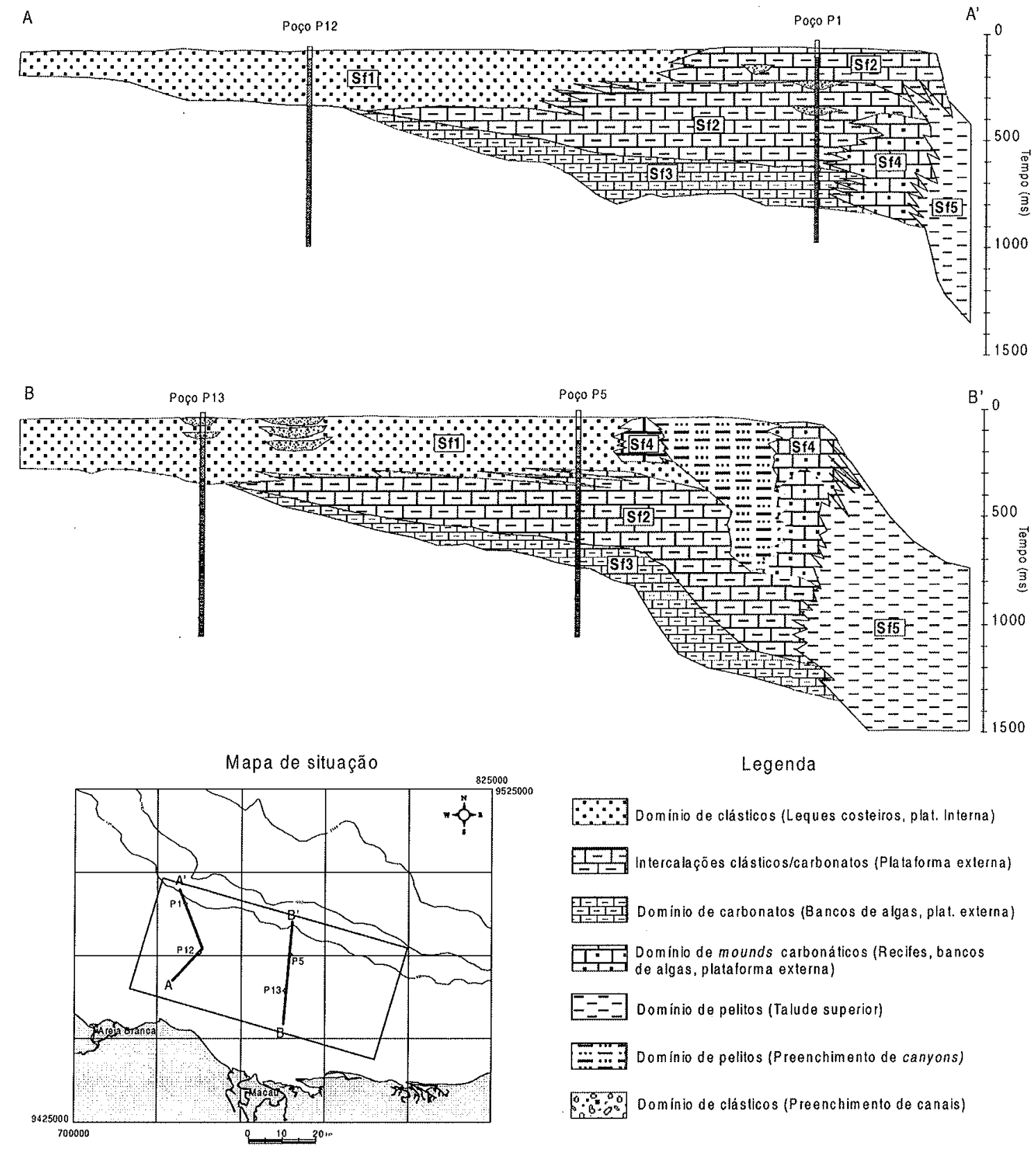

Legenda

$\because \because \because$ Dominio de clástlcos (Leques costêiros, plat. Interna)

I-1 Intercalą̧ōes clásticos/carbonatos (Platáorma externa)

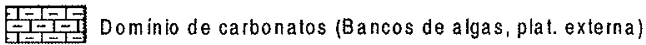

Dominio de mounds carbonáticos (Recifes, bancos

The algas, platatorma externa)

E-Z Dominio de pelitos (Talude superior)

F-..-3 Dominio de pelitos (Preenchimento de canyons)

$\therefore 0^{\circ}$ Dominio de clásticos (Preenchimento de canais)

Figura 7 - Sismofácies interpretadas como domínios de litofácies. A plataforma carbonática pura do Mioceno Inferior foi gradativamente preenchida pela cunha siliciclástica progradante, desde o Mioceno Médio até o Pleistoceno.

Os canais destes rios escavaram a plataforma durante os eventos de rebaixamento relativo do nível do mar, formando sistemas de vales incisos encaixados em calhas deposicionais. Estas calhas estão controladas por sistemas de falhas antigas, já ativas no Cretáceo, a julgar pela existência de cânions daquela idade coincidentes com estruturas profundas, possivelmente ancoradas no embasamento. Durante o Neogeno, novos cânions de dimensões bem mais modestas foram reativados, provavelmente pela atividade destes sistemas de falhas, capturando a drenagem na plataforma e concentrando a distribuição de clásticos para o talude e a bacia oceânica.

A influência da sedimentação fluvial na plataforma variou em função das flutuações do nível do mar. Durante os períodos de mar baixo, os rios depositaram areias grossas nas áreas dos vales incisos ou sob a forma de cunhas clásticas de mar baixo na plataforma externa e talude. Ao atingirem a quebra da plataforma, os rios entalharam ou ampliaram recortes já existentes, formando uma série de cânions, alguns dos quais são ativos até os dias atuais. A sedimentação clástica, condicionada pelas calhas deposicionais, foi capturada pelos cânions na plataforma externa.

Durante os períodos transgressivos, os rios foram confinados à porção proximal (costeira), a plataforma foi inundada, provocando o aumento geral da paleobatimetria em toda a sua extensão. A sedimentação carbonática atingiu então a sua maior pujança, com 


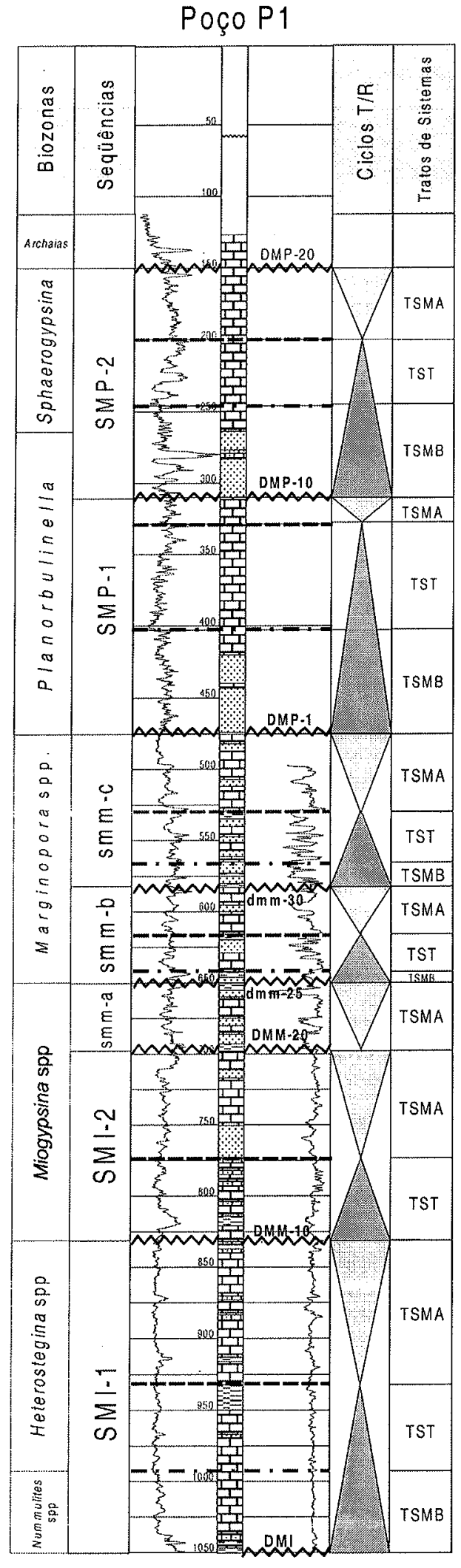

Figura 8 - Interpretação de tratos de sistemas nas seqüências deposicionais. Os tratos de mar baixo (TSMB), transgressivo (TST) e de mar alto (TSMA), foram interpretados a partir da integração das superficies-chave, feições sísmicas e seus correspondentes litológicos no poço PI. o franco desenvolvimento de recifes e bancos de algas e macroforaminíferos na plataforma externa e a invasão da plataforma interna durante os picos de máxima transgressão. Nesta fase, deu-se a deposição das fácies carbonáticas mais profundas ao longo de toda a extensão da plataforma. A influência da sedimentação clástica foi menor, restrita às oscilações de alta freqüência, quando o sistema foi eventualmente retomado por depósitos do trato de mar baixo.

Durante os períodos de mar alto, a sedimentação carbonática permaneceu ativa na plataforma externa enquanto nas calhas deposicionais avançaram cunhas clásticas progradantes a partir dos rios Açu e Mossoró. Estas cunhas parecem ter ficado restritas à porção proximal (plataforma interna). Raramente atingiram a plataforma externa ou simplesmente não se preservaram naquela porção da bacia. A sedimentação de mar alto na plataforma externa foi ainda dominada pela sedimentação carbonática, sob a forma dos mesmos bancos algálicos e recifes, que parecem ter sido os únicos depósitos que resistiram às erosões subsequientes.

Evolução paleoambiental A partir do modelodeposicional acima, foi possível determinar os cenários deposicionais dominantes nos três estágios que marcam a evolução paleoambiental da bacia no Neogeno: Mioceno Inferior/Médio, Mioceno Médio e Mioceno Superior/Pleistoceno.

MIOCENO INFERIORMÉDIO Este intervalo é marcado por dois eventos erosivos importantes (DMI, DMM-10), associados a grandes rebaixamentos relativos do nível do mar, com idades 17,6 e 15,5 Ma, respectivamente.

O evento erosivo DMI é reconhecido regionalmente nas bacias Potiguar e do Ceará como um marco de profundas mudanças no ambiente deposicional, dado pelo contato brusco entre sedimentos subjacentes de ambiente nerítico profundo (talude superior) e sobrejacentes de ambiente nerítico raso (plataforma carbonática). Esta mudança se reflete ainda na geometria deposicional, que apresenta caráter claramente progradacional nas sequiências terciárias mais antigas do que a DMI, passa a apresentar um forte componente agradacional a partir deste evento. Durante o rebaixamento eustático correspondente à DMI, a plataforma foi exposta à erosão subaérea ou, pelo menos, até o nível base de ondas normais, provocando o retrabalhamento de sedimentos do Oligoceno Inferior (biozona Nummulites spp.) durante o Eomioceno.

$\mathrm{O}$ ambiente deposicional neste período foi dominado por extensa plataforma carbonática, praticamente sem influxo de terrígenos e uma lâmina d'água relativamente profunda $(30$ - 40m). Os depósitos que caracterizam este intervalo são recifes e bancos de algas e foraminíferos bentônicos, interrompidos por níveis de packstones/wackestones, correspondentes a afogamentos periódicos da plataforma nos máximos transgressivos (Pessoa Neto 1999). O intervalo é marcado por ciclos carbonáticos, representando períodos alternados de produtividade alta em compasso com a acomodação e domínio de fácies recifais e períodos com baixa produtividade, marcados pelas fácies mais pelíticas, associados às inundações da plataforma.

Durante o período de deposição desta seqüência, os rios Mossoró e Açu estavam confinados ao continente e a disponibilidade de terrígenos para influxo também parece ter sido pequena, a julgar pela quase ausência de siliciclásticos nesta seção.

A presença de uma trama carbonática bem desenvolvida, a ausência de siliciciclásticos e a profundidade d'água elevada, indicam um período de mar relativamente alto neste período, com nível 


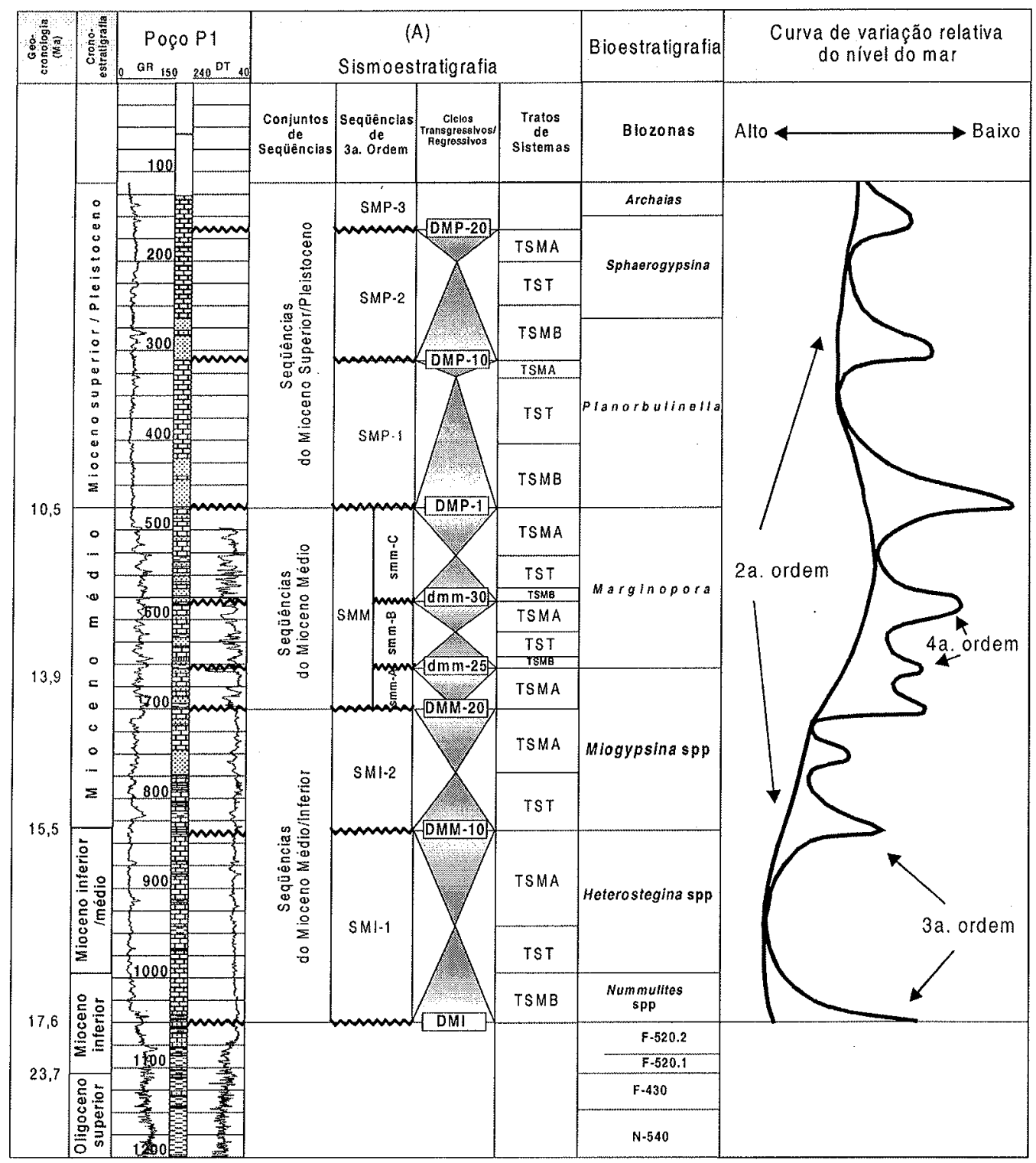

Figura 9 - Curva hipotética de variação relativa do nivel do mar, interpretada a partir da integração de dados da seção estudada. $O$ s limites de seqüências foram atribuídos a rebaixamentos relativos do nível do mar, enquantos os afogamentos regionais foram interpretados como resultantes dos níveis de máxima transgressão das seqüências.

máximo marcado por afogamento temporário da fábrica e deposição de lamas carbonáticas (Fig. 10).

MIOCENO MÉDIO A esta seção correspondem as seqüiências sísmicas SMI-2 e. SMM. A correspondência deste intervalo cronoestratigráfico com as sequiências sísmicas não é direta. A sequiência SMI-2, com geometria deposicional e sismofácies semelhantes à sequiência SMI-1 e faciologia semelhante à sequiência SMM, representa uma transição entre as condições ambientais existentes no Mioceno Inferior e Mioceno Médio.

Do ponto de vista paleoambiental, mudanças importantes podem ser observadas. A partir da DMM-10, que marca a base do intervalo, ocorrem os primẹiros pulsos de sedimentação terrígena na bacia, embora em volume subordinado em relação à produção de sedimentos carbonáticos. O aumento da sedimentação alóctone na bacia reflete um aumento na disponibilidade de siliciclásticos na área fonte, provavelmente associada à queda do nível de base por efeito de soerguimento continental. Estes sedimentos foram retrabalhados na plataforma interna e retransportados para a plataforma externa e bacia marinha, durante os rebaixamentos relativos do nível do mar.

Neste período, o sistema como um todo regrediu, com os recifes sendo gradativamente deslocados para a borda da plataforma e substituídos por bancos de algas vermelhas. Os ciclos carbonáticos puros, que marcam o intervalo anterior, são substituídos por ciclos de sedimentação mista, que vão caracterizar as seqüências de alta frequiência observadas no Mioceno Médio. Os períodos de sedimentação eminentemente siliciclástica são associados aos períodos de mar baixo e os carbonatos e folhelhos aos períodos de inundação da plataforma e mar alto. 

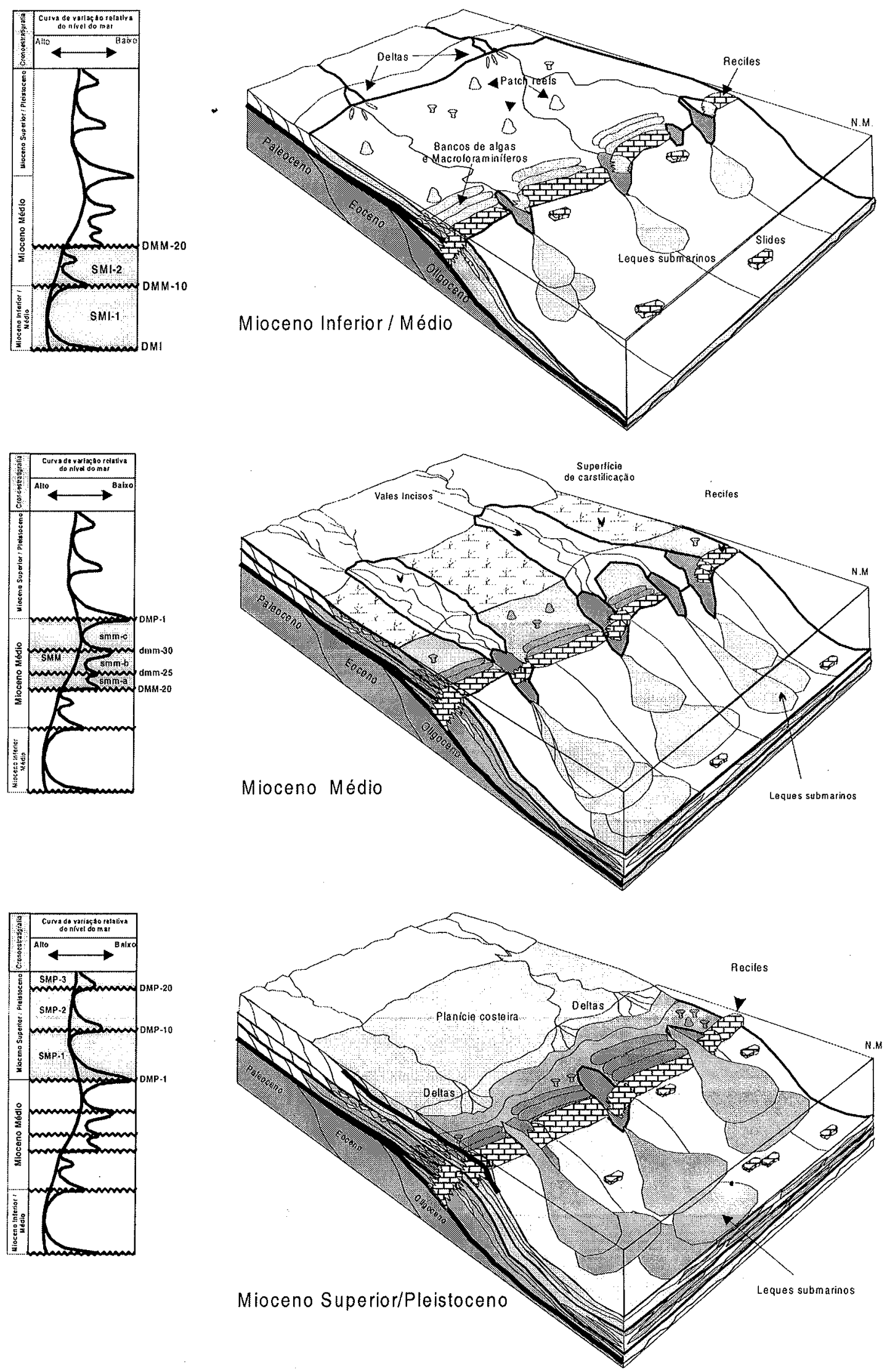

Figura 10 - Cenários deposicionais do Mioceno Inferior/Médio, Mioceno Médio e Mioceno Superior/Pleistoceno. 
As parassequiências que compõem as sequiências de $4^{\mathrm{a}}$ ordem na sequiência SMM têm espessuras reduzidas em relação às das demais da seção estudada. Esta relação entre as espessuras dos ciclos e as variações do nível do mar sugere a existência de um período de mar relativamente mais baixo durante o Mioceno Médio comparativamente ao ao Mioceno Inferior e Mioceno Superior/Pleistoceno. O período que corresponde a este intervalo representa, numa hierarquia de mais baixa frequiência das sequiencias ( $2^{\mathrm{a}}$ ordem), um período de mar relativamente mais baixo marcado pela superposição dos eventos de $3^{\mathrm{a}}$ ou $4^{a}$ ordens (Fig.10).

MIOCENO SUPERIOR/PLEISTOCENO Esta seção está representada pelas sequiências SMP-1, SMP-2 e SMP-3. A julgar pelo domínio de sedimentos terrígenos na maior parte dos poços analisados, sobretudo os situados próximos às calhas deposicionais da área, o influxo de siliciclásticos na bacia neste período é o mais alto de toda a seção de estudo deve-se a uma maior disponibilidade de sedimentos, em virtude do soerguimento epirogenético ocorrido na porção continental a sul da bacia a partir do Mioceno Inferior. Esta hipótese é consistente com a interpretação obtida a partir da análise de traços de fissão em apatita (Morais Neto 1999, Morais Neto et al. 2000). O poço P1, pelo fato de estar situado em uma zona de interflúvio, sofreu menos influência do aumento de aporte terrígeno.

A geometria das sequiências deste intervalo é eminentemente agradacional. Tal geometria e distribuição de fácies são devidas a um equilíbrio entre a criação de espaço deposicional e o al to influxo sedimentar, tanto de siliciclásticos como de carbonatos. $\mathrm{Na}$ porção proximal, a fábrica carbonática foi afogada pelo aumento do influxo de siliciclásticos, permanecendo ativa na plataforma externa, em porções protegidas da influência direta dos terrígenos. Mesmo nas porções adjacentes aos cânions a produção carbonática manteve-se durante este período (Fig. 10).

Esse intervalo representa um período de mar relativamente mais alto na freqüência das seqüências deposicionais de $3^{\text {a. }}$ ordem, superposto a um período de mar descendente na frequiência de $2^{\text {u. }}$ ordem.
CORRELAÇÃOREGIONALEGLOBAL A históriado Neogeno da Bacia Potiguar, no que diz respeito aos fatores que condicionaram a sua evolução deposicional proposta (eustasia, tectônica, suprimento sedimentar), está ligada a processos atuantes em escala regional ou global cujas variações ficaram impressas nas rochas estudadas. A correlação de eventos de magnitude regional ou global atuantes durante o Neogeno e os principais eventos registrados na Bacia Potiguar foi observada tanto em sinais tectônicos quanto glácio-eustáticos.

Tectônica A Província Borborema, unidade geotectônica onde situa-se a Bacia Potiguar, sofreu intenso soerguimento regional durante o Fanerozóico, provocando a remobilização de grandes massas sedimentares continentais em direção à margem. Este soerguimento foi descrito e interpretado por inúmeros autores desde o início do século (Morais Neto 1999)

Estudos recentes evidenciam a existência de pelo menos dois eventos de soerguimento epirogenético na porção oriental da província durante o Cenozóico, tendo o último iniciado há aproximadamente $20 \mathrm{Ma}$ (Morais Neto 1999, Morais Neto et al. 2000). Este último pulso poderia estar associado à intensa atividade vulcânica na porção continental (vulcanismo Macau), ocasionando, numa primeira fase, o soerguimento e posterior erosão das coberturas fanerozóicas expostas. A esta fase corresponderia a formação de discordâncias erosivas de magnitude regional.

Numa segunda fase, como conseqüência do soerguimento, as coberturas terciárias da Formação Serra do Martins teriam sido erodidas e redepositadas sob a forma de sistemas de leques aluviais e canais entrelaçados, com fácies flúvio-lagunares subordinadas, que compõem a Formação Barreiras (Alheiros \& Lima Filho apud Morais Neto 1999). A partir do Mioceno Superior/Pleistoceno, os depósitos da Formação Barreiras teriam sido retransportados para a bacia marinha, por efeito de amplificação do mesmo soerguimento regional (Fig. 11).

A esses dois eventos tectono-estratigráficos são correlacionados dois episódios marcantes na evolução da Bacia Potiguar submersa:

- a amplificação da discordância DMI, interpretada neste traba-
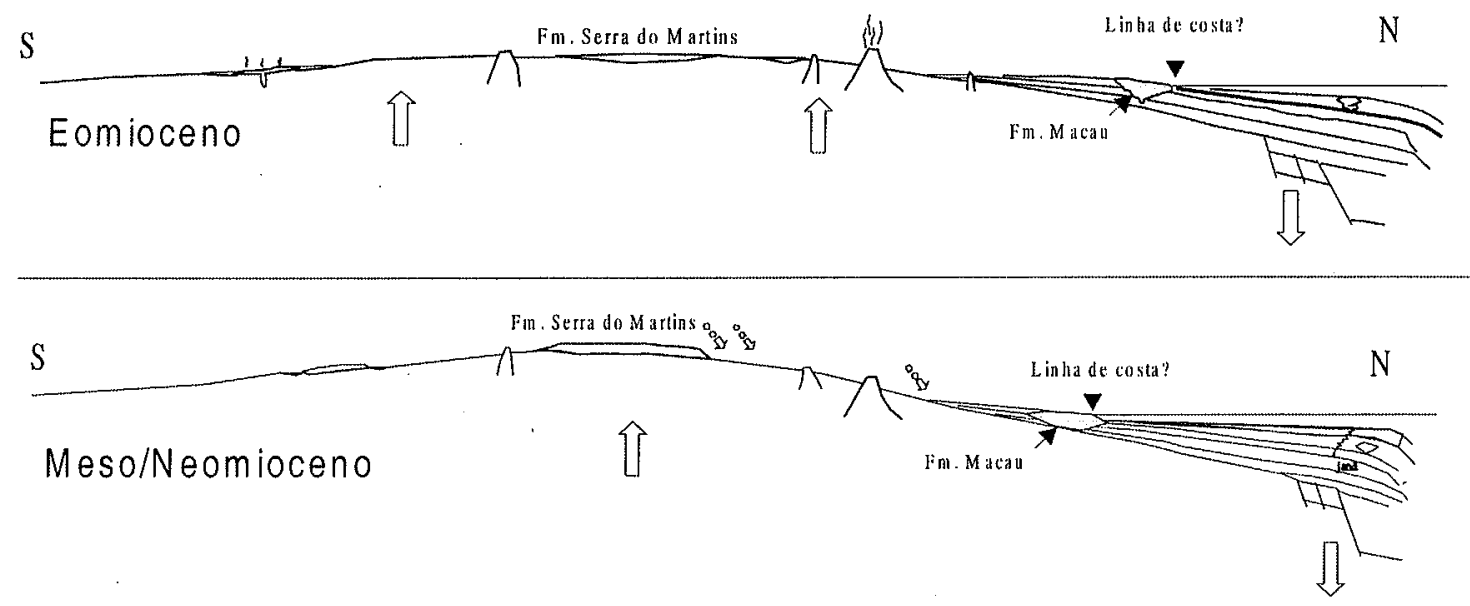

Figura 11 - Eomioceno: intensa atividade vulcânica na porção continental (novo pulso da Fm. Macau). Formação de importante discordância erosiva na porção submersa (ca $17 \mathrm{Ma}$ ). Meso/Neomioceno: erosão da Fm. Serra do Martins, com provável início da deposição da Fm. Barreiras e deslocamento da sedimentação siliciclástica na plataforma em direção à porção submersa da bacia 
Tho com idade 17,6 Ma;

- o aumento no influxo de siliciclásticos para a bacia a partir do Mioceno Superior.

A DMI, cuja formação coincide com um deslocamento geral de fácies para a bacia, é interpretada como resultado de um rebaixamento relativo do nível do mar, provocado pela conjugação, em fase, do soerguimento epirogenético regional com uma queda eustática de magnitude global. Tal rebaixamento é observado na curva de Haq et al. (1988) no período correspondente. Esta superposição dos componentes tectônico regional e eustático global pode explicar a magnitude pronunciada desta discordância nas bacias da margem equatorial, mais afetadas pelo referido evento do que nas bacias contemporâneas da margem leste.

A partir do Mioceno Superior/Pleistoceno, a bacia experimentou um aumento significativo no influxo de sedimentos siliciclásticos, via drenagem costeira formada pelos rios Açu e Mossoró. A este aumento no influxo de clásticos correspondem períodos de progradação de sedimentos na plataforma interna e agradação na plataforma externa dada pela grande atividade da fábrica carbonática. Este cenário aponta para um provável nível do mar relativamente alto e alta disponibilidade de clásticos na área fonte. Os siliciclásticos disponíveis na margem equatorial eram exatamente os depósitos aluviais e fluviais da Formação Barreiras, provenientes da segunda fase de soerguimento. Estes depósitos progradantes na plataforma interna correspondem litoestratigraficamente à Formação Tibau e os carbonatos domi- nantes na plataforma externa correspondem à Formação Guamaré.

Eustasia A utilização da curva global como parâmetro de construção de modelos geológicos baseados na correlação de eventos registrados em uma bacia e eventos supostamente de magnitude global tem sido bastante questionada na bibliografia. As restrições de uso desta ferramenta dizem respeito, principalmente, à baixa resolução dos métodos de datação bioestratigráfica e isotópica para resolver eventos de freqüências de $3^{\text {a. }}$ ordem ou mais altas (Posamentier \& James 1993) ou ainda em função da origem das variações nesta faixa de frequiências, que poderiam estar relacionadas, entre outras causas, a efeitos tectônicos locais como resultado da interação entre placas (Intraplate stress, Cloetingh 1988, 1991). Neste trabalho não se pretende comprovar ou contrariar o uso das curvas globais como ferramenta de correlação entre bacias, mas proceder-se uma correlação tentativa entre os eventos identificados na área estudada e os eventos observados na curva global de Haq et al. (1988). Admite-se, portanto, que as variações registradas na curva global podem estar refletidas nas variações relativas que controlam a criação ou redução do espaço disponível para acomodação de sedimentos. O sinal global pode estar obliterado, mascarado ou amplificado por fatores tectônicos ou climáticos locais, a depender da magnitude relativa dos processos geradores do espaço deposicional.

Tendo em mente estes princípios, procurou-se estabelecer uma correlação entre os eventos observados na seção estudada e a

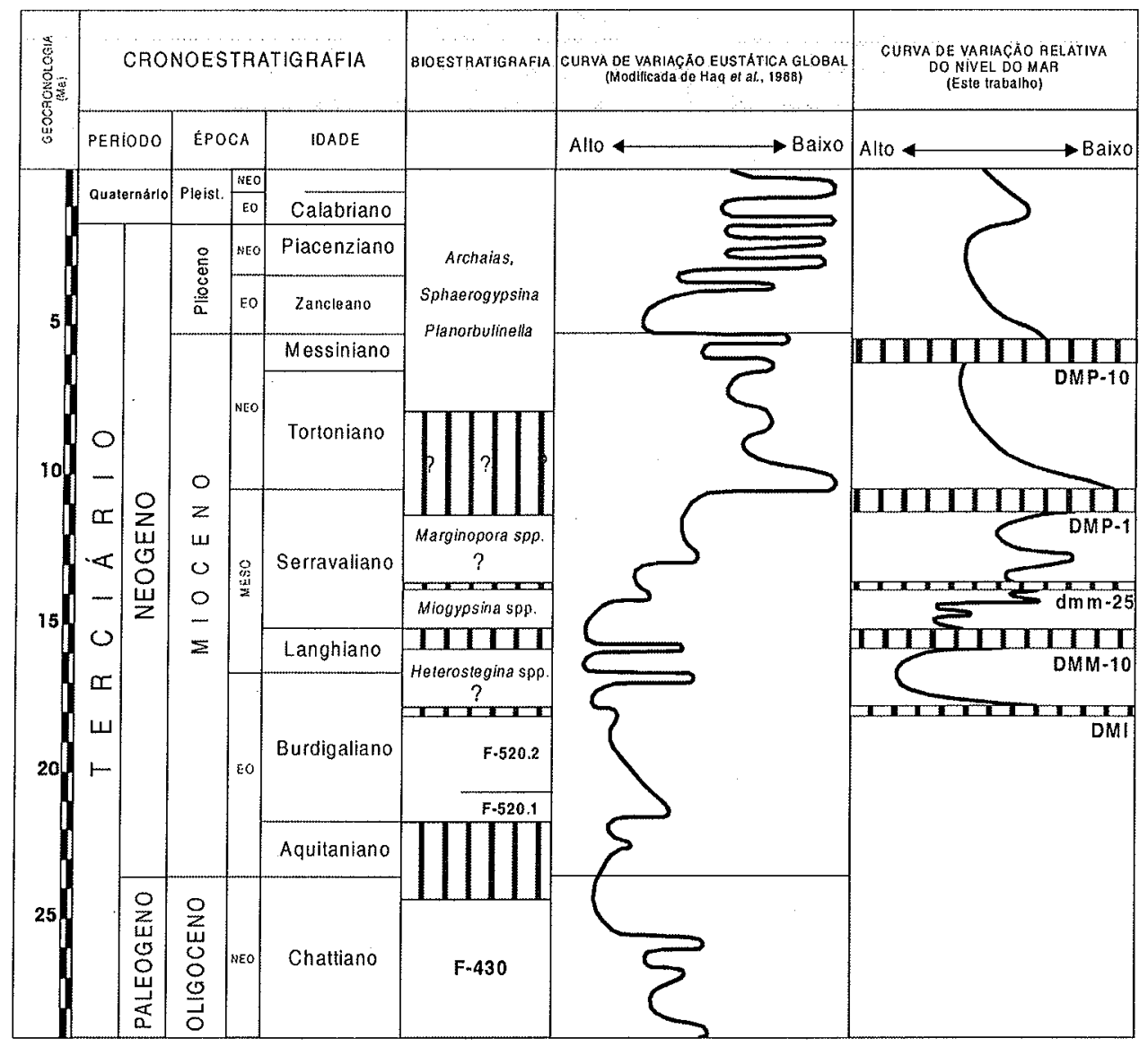

Figura 12 - Correlação entre os principais eventos erosivos observados na seção de estudo e a curva eustática global (Haq et al. 1988). 
curva global de Haq et al. (1988). Para proceder esta correlação foi necessário ajustar os dados da seção de estudo à escala de tempo da curva global, considerando o tempo representado pelo registro físico (rocha) e pelos hiatos (discordâncias). Feito este ajuste, foi possível correlacionar a curva de variações do nível do mar obtidas a partir dos dados analisados na área, calibrados pelo poço $\mathrm{P} 1$, e as variações eustáticas globais (Fig. 12). A correlação entre as duas curvas mostrou uma boa correspondência geral na freqüência equivalente à $2^{\mathrm{a}}$ e $3^{\mathrm{a}}$ ordens, com a coincidência temporal de algumas discordâncias da área com rebaixamentos observados na curva global.

Ao nível da segunda ordem, pode-se observar uma tendência geral de elevação eustática na seção correspondente ao Mioceno Inferior, entre 17,6 e 13,0 Ma, com máximo situado em torno de 15,5 Ma. Este período caracterizou-se pela retrogradação geral do sistema, com afogamento e retenção da drenagem dentro do continente, correspondendo ao trato transgressivo de $2^{\mathrm{a}}$ ordem na bacia. Tal intervalo corresponde à grande transgressão miocênica (Aquitaniano-Serravaliano), a mais expressiva do Terciário, ocasionando a deposição de sedimentos marinhos em áreas emersas em vários pontos da Terra (Shimabukuro \& Arai 1999). O período entre $10,5 \mathrm{Ma}$ e o presente caracteriza-se pela progradação seguida de agradação do sistema misto como um todo, correspondendo, pois, ao trato de mar alto na segunda ordem.

As sequiências de $2^{\mathrm{a}}$ ordem são pontuadas por eventos de $3^{\mathrm{a}}$ ordem possivelmente relacionados a rebaixamentos presentes na curva global. São eles:

DMI: conforme mencionada anteriormente, esta discordância coincide com um sutil rebaixamento da curva global (Haq et al. 1988), registrado ao redor dos $18 \mathrm{Ma}$. A formação da DMI foi datada neste trabalho com a idade aproximada de 17,6 Ma, com base em dados bioestratigráficos e isotópicos, portanto possivelmente correlacionável ao evento global (Fig. 12). A sua magnitude e expressão regional são aqui interpretadas como fruto da conjunção entre este evento eustático e o efeito do soerguimento neogênico experimentado pela Província Borborema (Morais Neto 1999, Morais Neto et al. 2000).

DMM-10: este evento corresponde à extinção do gênero Heterostegina spp., com valor absoluto interpretado em torno dos 15,5 Ma. Este evento mostra correspondência temporal razoável com expressivo rebaixamento eustático do Mesomioceno (Fig. 12), marcando o primeiro influxo significativo de siliciclásticos na seção neogênica na área de estudo.

dmm-25: esta discordância marca a extinção do gênero Miogypsina spp., sendo interpretada por Abreu et al. (1993) como uma descontinuidade de alcance regional nas bacias da margem equatorial, podendo estar relacionada com rebaixamento observado na curva global. Neste trabalho, a dmm-25 é interpretada como cronologicamente correspondente ao rebaixamento de $3^{\text {a }}$ ordem observado entre 13 e 14 Ma na curva eustática global .

DMP-1: esta discordância marca um expressivo rebaixamento relativo do nível do mar na área de estudo e inaugura uma fase de alto influxo de siliciclásticos na bacia. A despeito da falta de evidências definitivas que comprovem a correlação, a ocorrência de um evento global com idade equivalente ao Tortoniano (10,5 Ma) é sugestiva da correspondência entre os dois eventos. A baixa resolução bioestratigráfica da seção superior não permite o posicionamento cronoestratigráfico preciso deste evento, embora seja possível datá-lo como pertencente ao Mioceno Superior. Este evento foi observado em outras bacias da margem brasileira.
Viana et al. (1990) interpretaram-no como responsável pela geração de expressiva discordância erosiva na Bacia de Campos, denominada de Marco Cinza. Abreu et al. (1993) atribuem a este evento o desaparecimento das associações dominadas por miogipsinídeos em praticamente todas as plataformas carbonáticas da margem equatorial brasileira.

A seção correspondente às seqüências do Mioceno Superior/ Pleistoceno não pôde ser melhor correlacionada em função da baixa resolução bioestratigráfica e por falta de controle da espessura da seção superficial omitida no poço P1, situada entre o fundo do mar e a primeira amostra do poço. Ė sugestiva a correlação entre o rebaixamento observado na curva global no topo do Messiniano e a discordância DMP-10, ainda que não se disponha de maiores evidências para sua confirmação.

Carta estratigráfica do Neogeno da Bacia Potiguar A carta estratigráfica da seção de estudo é apresentada na figura 13 , contendo apenas os eventos de maior magnitude ( $3^{\text {a }}$ ordem) e seus respectivos registros litológicos. A abrangência lateral da carta restringe-se aos ambientes de plataforma interna e externa que correspondem à porção da bacia abordada neste trabalho. Verticalmente, a carta focalizou o intervalo compreendido na pesquisa, que vai do Mioceno Inferior ao Holoceno.

CONCLUSÕES A partir do arcabouço cronoestratigráfico estabelecido, alguns aspectos relativos à sedimentação mista foram explorados e tentativamente esclarecidos, enquanto muitos outros continuam ainda por serem desvendados. Algumas conclusões dizem respeito aos ambientes mistos de uma maneira geral, outras se referem a particularidades da seção ou área estudada, mas que ganharam importância a partir de sua descoberta ou reconhecimento. São elas:

- a estratigrafia de sequiências funcionou bem como modelo de análise estratigráfica de seções caracterizadas por sedimentação mista na Bacia Potiguar;

- os períodos de mar baixo foram marcados por uma maior expressão da sedimentação siliciclástica, enquanto os períodos de mar ascendente ou estável favoreceram a sedimentação carbonática.

- o principal mecanismo modulador da acomodação na seção estudada foi a eustasia;

- a tectônica, marcada por eventos de soerguimento epirogenético regional, atuou como amplificador de eventos erosivos e agente principal no influxo siliciclástico na bacia;

- Os rios Açu e Mossoró se implantaram na sua posição atual pelo menos desde o Mioceno Médio, atuando como sistemas de vales incisos durante os múltiplos rebaixamentos do nível do mar;

- foi possível correlacionar eventos de natureza tectono-eustática e glácio-eustática em escalas regional e global, respectivamente, com discordâncias identificadas na seção estudada.

Agradecimentos À Petrobras, pela liberação dos dados e permissão de publicação deste trabalho; aos colegas João Marinho de Morais Neto, Diógenes Custódio de Oliveira, César Cainelli, René Rodrigues e Jeferson Dias pelas sugestões; aos colegas do Cenpes, em especial à Marta Cláudia pelos dados e discussões da bioestratigrafia; aos colegas e professores do CPGGeo/UFRGS, em especial aos professores Valesca Lemos e Gerson Terra pelas discussões técnicas. Ao colega Roberto d'Ávila e aos revisores da RBG pelas sugestões ao manuscrito. 


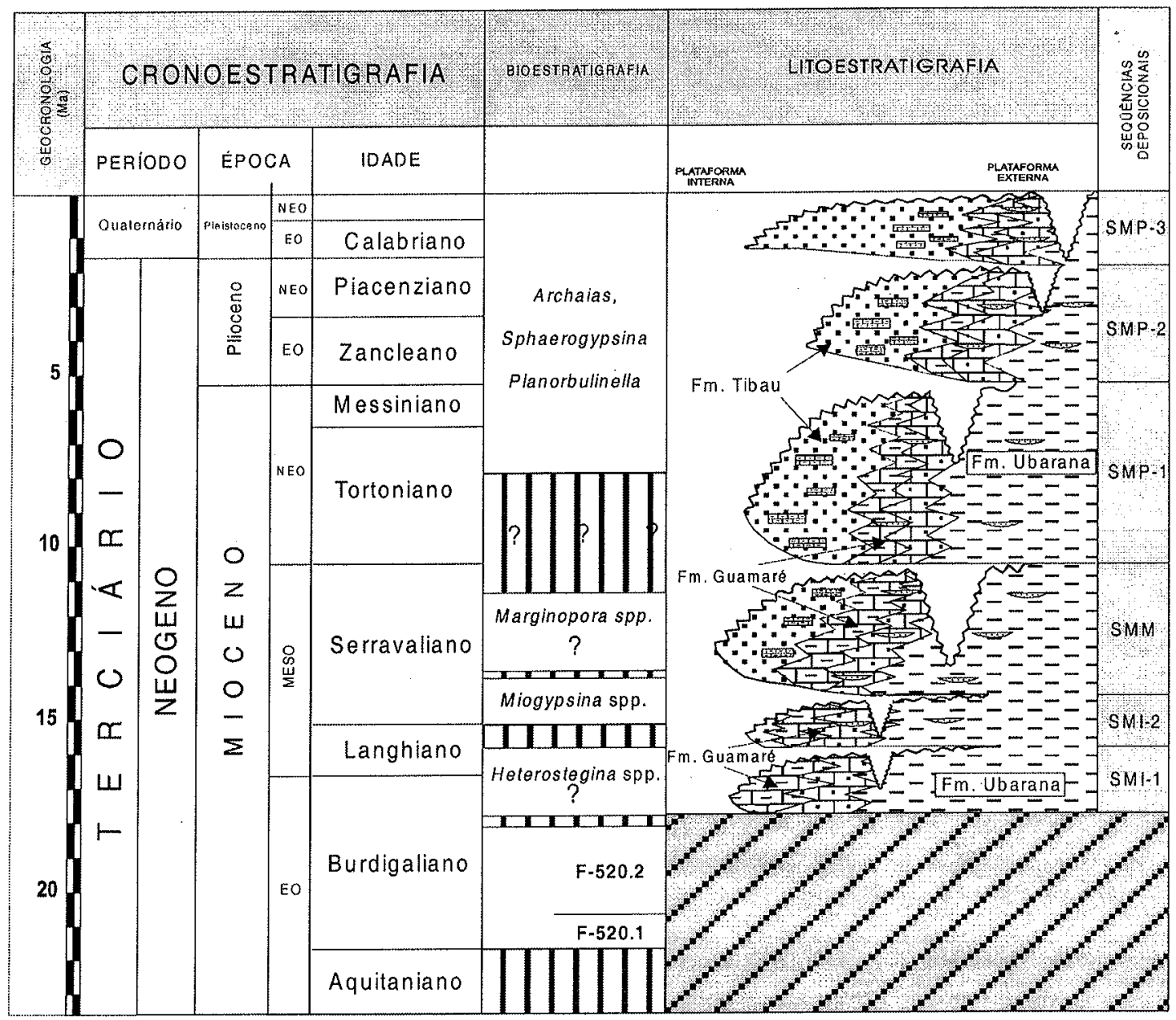

Figura 13 - Carta estratigráfica da seção estudada, contendo apenas os eventos de maior magnitude e seus respectivos registros litológicos.

\section{Referências}

Abreu W.S., Regali M.P.S., Shimabukuro S. 1986. O Terciário da plataforma continental do Maranhão e Pará, Brasil. Bioestratigrafia e evolução paleoambiental. In: SBG, Congr. Bras. Geol., 34, Goiânia, Anais, 1: 145 - 159.

Abreu W.S. \& Viviers M.C. 1991. Considerações sobre a distribuicão de macroforaminíferos em estratos pós-Oligoceno Inferior da margem continental brasileira. In: USP, Congr. Bras. Paleont., 12, São Paulo, Boletim de Resumos, p. 97.

Abreu W.S., Viviers M.C., Antunes R.L. 1993. Bioestratigrafia e paleoecologia das seções carbonáticas terciárias das bacias Potiguar, Ceará e ParálMaranhão, com base em macroforaminíferos - Parte I (Oligoceno Superior - Recente), Rio de Janeiro, Petrobras/Cenpes, 45 p. (Relatório Interno).

Araripe P.T. \& Feijó F.J. 1994. Bacia Potiguar. Bol. Geoc. da Petrobras, 8: $127-141$

Bertani R.T., Costa I.G. , Matos R.M.D. 1990. Evolução tectonosedimentar, estilo estrutural e habitat do petróleo na Bacia Potiguar. In: Gabaglia G.P.R. \& Milani E.J. (eds.) Origem e Evolução das Bacias Sedimentares, Petrobras, Rio de Janeiro, p. 291-310.
Chang H.K. \& Kowsmann R.O. 1987. Interpretação genética das sequiências estratigráficas das bacias da margem continental brasileira. Rev. Bras. Geociências, 17: 74-80.

Chang H.K., Kowsmann R.O., Figueiredo A.M.F., Bender A.A. 1992. Tectonics and stratigraphy of the East Brazil Rift System: an overview. Tectonophysics, 213: 97-138.

Cloething S. 1988. Intraplate stresses: a tectonic cause for third-order cycles in apparent sea level? In: Wilgus C.K., Kendall C.G.ST.C., Posamentier H.W., Ross C.A., Van Wagoner J.C. (eds.) Sea-level changes: an integrated approach, Tulsa, SEPM, p. $19-29$, (Special Publication, 42).

Cloething S. 1991.Tectonics and sea level changes: A controversy?, In: Müller D.W., McKenzie J.A., Weissert H. (eds.) Controversies in Modern Geology, Academic Press Ltd., p. 249 - 277.

Della Fávera J.C., Castro J.C., Soares U.M., Rossetti E.L., Matsuda N., Hashimoto A., Guzzo J.P., Rodrigues R., Azambuja N.C., Alves D.B. 1994. Estratigrafia de seqüências da Formação Pendência, Bacia Potiguar. In: Simpósio sobre o Cretáceo no Brasil, 3, Rio Claro, Resumos, p. 35. 
Haq B.U., Hardenbol J., Vail P.R. 1988. Mesozoic and Cenozoic Chronostratigraphy and cycles of sea level change. In: Wilgus C.K., Kendall C.G.ST.C., Posamentier H.W., Ross C.A., Van Wagoner J.C. (eds.) Sea-level changes: an integrated approach, Tulsa, SEPM, p. 71 - 108. (Special Publication, 42).

Matos R.M.D. 1987. Sistema de "rifts" cretáceos do Nordeste Brasileiro. In: Seminário de tectônica da Petrobras, 1, Rio de Janeiro, Atas, Petrobras/Depex, p. $126-159$.

Matos R.M.D. 1992. The northeast brazilian rifts system. Tectonics, 11: 766-791.

Morais Neto J.M. 1999. As coberturas sedimentares terciárias do interior da Paraíba e Rio Grande do Norte e a gênese da Antéclise da Borborema. Universidade Federal de Ouro Preto, Ouro Preto, Dissertação de Mestrado, 170 p.

Morais Neto J.M., Hegarty K.A., Alkmin F.F, Matos R.M.D., Karner G. 2000. Uplift and Erosion in the Borborema Province, NE Brazil: Insights from Apatite Fission Track Analysis. 31st Intern Geol. Cong., Absiracts, Rio de Janeiro.

Pessoa Neto O.C. 1999. Análise estratigráfica integrada da plataforma mista (siliciclástica-carbonática) do Neogeno da Bacia Potiguar, NE do Brasil. Curso de Pós-Graduação em Geociências, Universidade Federal do Rio Grande do Sul, Porto Alegre, Dissertação de Mestrado, $220 \mathrm{p}$.

Posamentier H.W. \& James D.P. 1993. An overview of sequence stratigraphy concepts: uses and abuses. In: Posamentier H.W., Summerhayes C.P., Haq B.U., Allen G.P. (eds.) Sequence Stratigraphy and facies associations. Oxford: Blackwell, p. 3-18 (IAS, Special Publication, 18).

Shimabukuro S. \& Arai M. 1999. A transgressão marinha miocênica no Brasil: considerações baseadas no estudo do Grupo Barreiras e da Fm Pirabas. Anais da Academia Brasileira de Ciências, 71: 144.

Soares U.M., Goulart J.P.M., Brito A.F., Cremonini O.A., Ramos M.A. 1999. Projeto de integração geológica-geofísica da porção submersa da Bacia Potiguar, Natal, Petrobras (Relatório interno).

Souza S.M. 1982. Atualização da litoestratigrafia da Bacia Potiguar. In: SBG, Congr. Bras.Geol., 31, Salvador, Anais, 5: 2392 - 2406.

Vasconcelos E.P. 1995. O evento CPT (Camadas Ponta do Tubarão) Aptiano da Bacia Potiguar. Curso de Pós-Graduação em Geociências, Universidade Federal do Rio Grande do Sul, Porto Alegre, Dissertação de Mestrado, 198 p.

Viana A.R., Kowsmann R. O., Castro D. D. 1990. A discordância do Mioceno médio superior: um marco regional no talude da Bacia de Campos. In: SBG, Cong. Bras. Geol., 36, Natal, Anais, 1: 313 -323.

Manucsrito A-1345

Recebido em 17 de maio de 2002

Revisão do autor em 05de agosto de 2003 Revisão aceita em 10 de agosto de 2003 